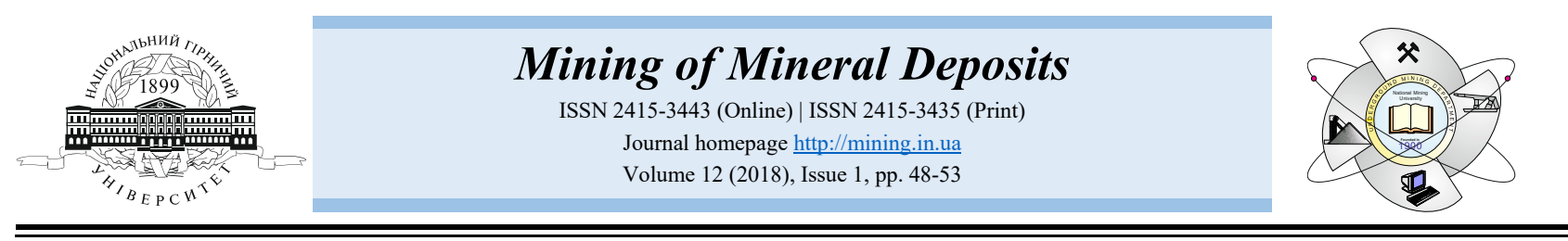

UDC 65.012 .122

https://doi.org/10.15407/mining12.01.048

\title{
SOFTWARE APPLICATION IN MINING ENGINEERING
}

\author{
Mahrous A.M. Ali ${ }^{1 *}$

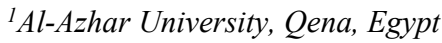 \\ *Corresponding author: e-mail mahrous mining@yahoo.co.uk, tel. +20963210223, fax: +20963210223
}

\begin{abstract}
Purpose. The main purpose is solving transportation problems using some methods of transportation modeling by linear programming. Linear programming has already demonstrated its value as an aid to making decisions in mining, business, industry, and governmental applications. This paper discusses how to solve transportation problems using manual solution method and computer software solutions. The transportation model deals with a special case of linear programming problems whose objective is to "transport" a single commodity from various "points of departure" to different "destinations" at minimum total cost.
\end{abstract}

Methods. In this paper, we used manual and computer software to solve many problems in mining engineering.

Findings. The optimum solution for the problems occurring in the mine site, which will apply for future problems in different conditions, has been obtained. It was proved that results are identical because they produce the same effect when solving the problem using the following five methods: northwest corner method; minimum cost method; row minimum cost method; column minimum cost method, and Vogel's approximation method.

Originality. The new trend is how to use computer application in solving all mining problems and obtain the optimum solution for any problem considering the constraints.

Practical implications. All the suggested solutions are optimum ways to solve mining problems which can be applied to any problem beyond the studied field.

Keywords: transportation problem, linear programming, Microsoft Excel solver, Lindo software

\section{INTRODUCTION}

The main purpose is solving transportation problem using some methods of transportation model by linear programming (LP). Linear programming has already demonstrated its value as an aid to making decision in business, industry, and governmental applications (Ilich, 2008; Qi, Tian, \& Shi, 2012; Antipin \& Khoroshilova, 2015; Astola \& Tabus, 2016). Determination of facility or machine scheduling, distribution of commodities, determination of optimum products mix, and allocation of labor and other resources are few examples of the problems that can be solved by linear programming.

Linear programming is a subclass of allocation models. It is a method of allocating scarce resources to compete activities under the assumption of linearity (Da Gama, 2012). In linear programming problem (LPP), both the objective function and the constraints are assumed to be linear. In other words, linear programming deals with problems whose structure is made up of variables having linear relationships with each other. Linear programming is used either to maximize or to minimize a given objective function (Loomba, 1964).

The transport, as a special case for linear programming problems, is one of the most important and successful applications of quantitative analysis to solve business problems in production and transportation. Basically, the purpose is to minimize the cost of shipping goods from one location to each arrival area within its capacity. Transport represents high percent of the mining operating costs, especially in building construction materials (Reeb $\&$ Leavengood, 2001). The aim of this work is to set up transport problems and solve them using the simplex method applied to any linear programming problem.

\section{MANUAL SOLUTION}

The transport model deals with a special case of linear programming. The objective "transport" is a single commodity from various "points of departure" to different "destinations" with minimum total cost. Transport as a linear-programming problem can always be solved by 
the simplex method. This problem consists essentially of three components.

1. Linear Objective Function. Every linear programming problem has objective function (maximization or minimization) in the form:

$$
f(x)=\sum c_{i j} \cdot x_{i j},
$$

where:

$$
\begin{aligned}
& i=1,2 \ldots m \\
& j=1,2 \ldots n \\
& x_{i j}-\text { set of structural variables; } \\
& c_{i j} \text { - set of the so-called "price coefficients"; }
\end{aligned}
$$

$f(x)=c_{11} x_{11}+c_{21} x_{22}+\ldots c_{m n} x_{m n}$.

2. Linear Structural Constraints. Every linear programming problem contains a set of linear constraints:

$$
\sum \sum x_{i j}>b_{j} ; \sum \sum x_{i j}<a_{i}
$$

where:

$$
\begin{aligned}
& i=1,2 \ldots m ; \\
& j=1,2 \ldots n .
\end{aligned}
$$

The embodied technical specification and resource capacity of the problem structure are therefore called structural constraints. These constraints in the form of the linear structure are given below:

$$
\begin{gathered}
x_{11}+x_{12}+\ldots+x_{1 n} \leq a_{1} \\
x_{21}+x_{22}+\ldots+x_{2 n} \leq a_{2} \\
\ldots \ldots \ldots \ldots \ldots \ldots \ldots \ldots \ldots \ldots \ldots \ldots \ldots \ldots \ldots \ldots \ldots \ldots \ldots \ldots \ldots \\
x_{m_{1}}+x_{m 2}+\ldots+x_{m n} \leq a_{m}
\end{gathered}
$$

and

$$
\begin{aligned}
& x_{11}+x_{12}+\ldots+x_{1 n} \leq a_{1} \\
& x_{21}+x_{22}+\ldots+x_{2 n} \leq a_{2}
\end{aligned}
$$

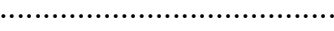

$$
\begin{aligned}
& x_{m 1}+x_{m 2}+\ldots+x_{m n} \leq a_{m} \text {. }
\end{aligned}
$$

3. Non Negativity Constraints. The structural variables, slack and artificial slack variables of all linear programming problems are restricted by nonnegative values. This is accomplished by imposing nonnegative constraints in the form $-x_{i j} \geq 0$, where $(i=1,2 \ldots m$, $j=1,2,3 \ldots n)$ (Saul, 1957).

There are five methods solving transportation problem manually.

1. Northwest Corner method. According to this method, first allocation is made to the cell occupying the upper left-hand (Northwest) corner of the matrix. Further, this allocation of the individual elements of the array appears in cells and represent a solution. An empty cell denotes the value of zero.

Step 1. Start with the cell in the upper left-hand corner.

Step 2. Allocate the maximum feasible amount consistent with row and column sum requirements involving that cell. At least one of these requirements will then be met.

Step 3. Move one cell to the right if there is any remaining row requirement (supply).
Otherwise, move one cell down. If all requirements are met, stop; otherwise go to step 2 (Loomba, 1964).

2. Minimum cost method. Here we search the whole matrix for the smallest element and allocate accordingly. We repeat this procedure until all the units are shipped.

3. Vogel's approximation method.

Step 1. For each row of the transportation table, identify the smallest and the next-to-smallest costs. Determine the difference between them for each row. Display them alongside the transportation table by enclosing them in parenthesis against the respective rows. Similarly compute the differences for each column.

Step 2 identifies the row or column with the largest difference among all the rows and columns. If a tie occurs, use any arbitrary tie breaking choice. Let the greatest difference correspond to $i^{\text {th }}$ row and the minimum cost be $c_{i j}$. Allocate a maximum feasible amount $x_{i j}=\min \left(a_{i}, b_{j}\right)$ in the $(i, j)^{\text {th }}$ cell, and cross off the $i^{\text {th }}$ row or $j^{\text {th }}$ column.

Step 3. Recompute the column and row differences for the reduced transportation table and go to step 2 .

Repeat the procedure until the entire rim requirements are satisfied.

4. Row Minimum Method. Let the minimum element in the first row be $c_{1 k}$. If there are more than one minimum element, select the one with the smallest index $j$.

Let $x_{1 k}=a_{1}$, if $a_{1} \leq b_{1}$ or $x_{1 k}=b_{k}$ of $a_{1}>b_{k}$.

In the first case, we have shipped all the $a_{1}$ units and go on to the second row after changing $b_{k}$ to $b_{k}-a_{1}$. Next, we find the minimum elements in the second row and repeat the process. In the second case, we have allocated only $b_{k}$ units of the $a_{1}$ to $a_{1}-b_{k}$ and $b_{k}$ to zero and find the next smallest $a_{i j}$ in the first row and repeat the process.

5. Column Minimum Method. Here the calculations are similar to that using the row minimum. But in this case, we start with the first column and proceed to the next column.

\section{COMPUTER SOLUTION}

First let us formulate the transportation problem and set it up as "regular" linear programming problem using two LP Softwares (premium solver platform (PSP) and Lindo). The solution of both linear programs is optimum. In this paper, the solution with manual and programming methods is compared in terms of time and difficulty (Rao, 1978).

\section{CASE STUDY}

\subsection{Case study 1}

The first example is the $x y z$ sawmill company transportation problem, as shown in Table 1.

Table 1. Sawmill transportation problem (Example 1)

\begin{tabular}{ccccc}
\hline $\begin{array}{c}\text { Site / Mill } \\
\text { name }\end{array}$ & Mill A & Mill B & Mill C & $\begin{array}{c}\text { Availa- } \\
\text { bility }\end{array}$ \\
\hline Site 1 & 90 & 100 & 130 & 20 \\
Site 2 & 100 & 140 & 100 & 15 \\
Site 3 & 100 & 80 & 80 & 10 \\
Requirements & 5 & 20 & 20 & 45 \\
\hline
\end{tabular}

This example, solved by the two manual solutions mentioned above, gives the same solution by the two computer methods used here. It is found that the manual 
solution consumes more time than the computer solution. It is found also that Lindo program takes more time to solve Example 1 than the premium solver platform. The solution steps for the four mentioned methods ( 2 manual +2 computerized) are summarized as follows.

\subsubsection{Solution of Example 1 \\ by the Northwest Corner Method}

To solve the problem using the northwest corner method, it takes five stages to distribute the availabilities with requirements by the given steps $(1,2,3,4)$ of the method mentioned before. Table 2 presents the solution.

Table 2. The final solution of Example 1, by Northwest Corner Rule

\begin{tabular}{|c|c|c|c|c|c|c|c|}
\hline $\begin{array}{l}\text { Dressing } \\
\text { plants }\end{array}$ & \multicolumn{2}{|c|}{ Mill A } & \multicolumn{2}{|c|}{ Mill B } & \multicolumn{2}{|c|}{ Mill C } & $\begin{array}{l}\text { Avai- } \\
\text { lability }\end{array}$ \\
\hline Site 1 & 5 & 90 & 15 & 100 & & 130 & 20 \\
\hline Site 2 & & 100 & 5 & 140 & 10 & 100 & 15 \\
\hline Site 3 & & 100 & & 80 & 10 & 80 & 10 \\
\hline $\begin{array}{l}\text { Require- } \\
\text { ments }\end{array}$ & & 5 & & & & & \\
\hline
\end{tabular}

The solution in Table 2 is not necessarily optimum. So, we have to check it up to know if it is optimum or not. The check is repeated, until the optimumity is achieved. Five stages are required for this simple problem to reach the optimum condition. It means that this method needs long time to calculate the optimum solution (Abdelkhalik \& Mostafa, 1977; Waqar Ali Asad \& Dimitrakopoulos, 2012).

\subsubsection{Solution of Example 1} by Vogel's Approximation Method

Example 1 is solved by Vogel's approximation method. It also incorporates five stages. The comparison between this method and the North-west corner rule shows that the solution of Vogel's approximation method testifies that the optimum solution found by the North-west corner rule is close to the optimum solution (Reeb \& Leavengood, 2001).

\subsubsection{Solution of Example 1 by Lindo Software}

To solve the previous problem by Lindo Software (version 6), the following steps must be performed:

- put in the objective function like this (min $\left.90 x_{11}+100 x_{12}+\ldots\right)$;

- put in constraints as follows: $\left(x_{11}+x_{12}+x_{13} \geq 20\right)$, $\left(x_{21}+x_{22}+x_{23} \geq 15\right),\left(x_{31}+x_{32}+x_{33} \geq 10\right),\left(x_{11}+x_{21}+x_{31} \leq 5\right)$, $\left(x_{12}+x_{22}+x_{32} \leq 20\right),\left(x_{13}+x_{23}+x_{33} \leq 20\right)$, as shown in Figures 1, 2 (Abdelkhalik \& Mostafa, 1977).

\subsubsection{Solution of Example 1 by using Premium Solver Platform Method}

This program is operated under Excel software. The parameters of linear programming can be easily written through the cells of Excel worksheet as shown in Table 3. The objective function and constraints are put in the same worksheet because all cells must be linked with all cells.

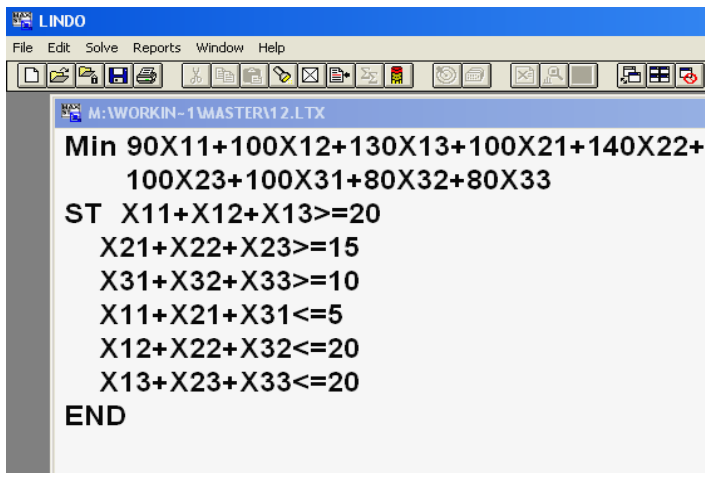

Figure 1. The objective function and constraint

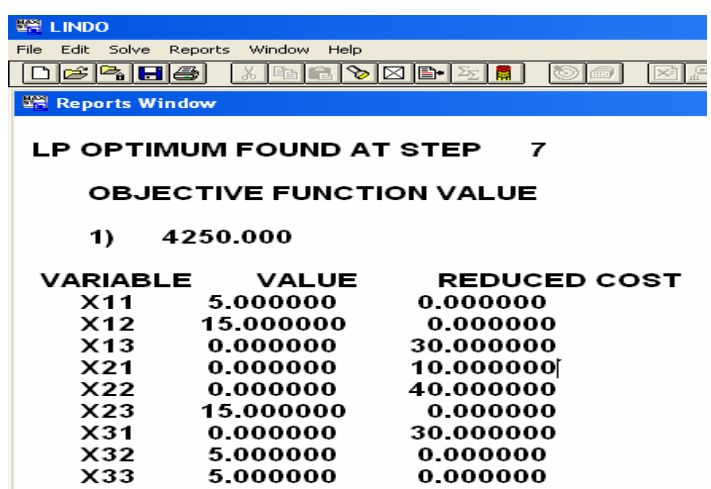

Figure 2. Final results after the software run

This program gives a dialogue indicating the type of solution (feasible, infeasible, and optimum) (David, 1984; Shalaby, 2000; Peter, 2005). The data input, constraints and results are in the same worksheet as in Table 3.

Table 3. Excel worksheet indicates Example 1 data and the results obtained

\begin{tabular}{ccccc}
\hline Site / Cost to center & \multicolumn{3}{c}{ Transportation cost } \\
to center $\left(c_{j}\right)$ & $\begin{array}{c}\text { Availabi- } \\
\text { lities }\left(b_{i}\right)\end{array}$ \\
\hline Plant & 1 & 2 & 3 & \\
1 & 90 & 100 & 130 & 20 \\
2 & 100 & 140 & 100 & 15 \\
3 & 100 & 80 & 80 & 10 \\
Requirements $(d i)$ & 5 & 20 & 20 & \\
Decision variables & \multicolumn{5}{c}{ Variables $\left(x_{i j}\right)$} & \\
1 & 5 & 15 & 0 & \\
2 & 0 & 0 & 15 & \\
3 & 0 & 5 & 5 & \\
Constraints & & & & \\
& 0 & & & \\
& 0 & & \\
Objective Function & 0 & 0 & \\
Total cost & 4250 & & \\
\hline
\end{tabular}

\subsection{Case study 2}

Sun Ray Transportation Company ships truckloads of grain from three silos to four mills. The supply (in truckloads) and the demand (also in truckloads) together with the unit transportation costs per truckload on different routes are summarized in the transportation model in Table 4. 
Table 4. Transportation model of the example (Sun Ray Transportation)

\begin{tabular}{cccccc}
\hline Site / Supply & 1 & 2 & 3 & 4 & Supply \\
\hline 1 & 10 & 2 & 20 & 11 & 15 \\
2 & 12 & 7 & 9 & 20 & 25 \\
3 & 4 & 14 & 16 & 18 & 10 \\
Demand & 5 & 15 & 15 & 15 & \\
\hline
\end{tabular}

The model seeks for the minimum-cost shipping schedule between the silos and the mills. This is equivalent to determining the quantity $x_{i j}$ shipped from silo $i$ to mill $j(i=1,2,3 ; j=1,2,3,4)$ (Abdelkhalik \& Mostafa, 1977; Gomah \& Samy, 2009).

\subsubsection{Solution of Example 2 by the Northwest Corner Method (manual method)}

The application of the procedure to the model of the example gives the starting basic solution in Figure 3.

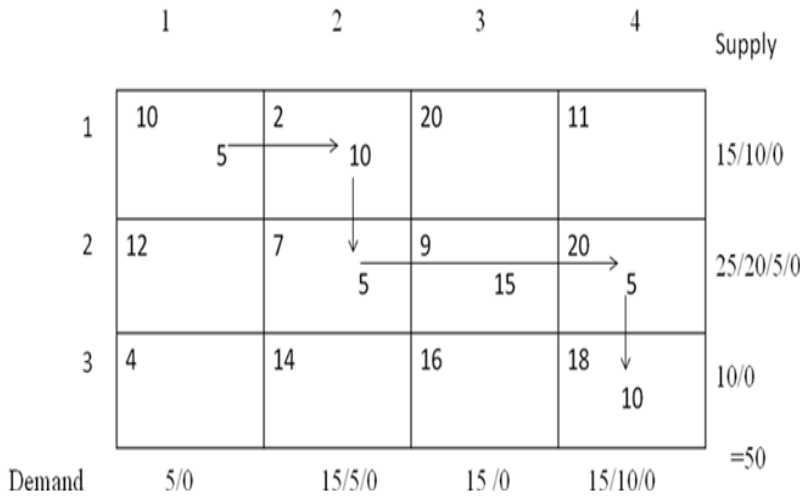

Figure 3. Northwest corner method (manually)

The starting basic solution is given as: $x_{11}=5$, $x_{12}=10, x_{22}=5, x_{23}=15, x_{24}=5, x_{34}=10$.

The objective function value is: $F(x)=5 \cdot 10+10 \cdot 2+$ $+5 \cdot 7+15 \cdot 9+5 \cdot 20+10 \cdot 18=\$ 520$

But this solution is not optimum because the objective function is not the minimum, so after that the optimum solution is given in Table 5 .

Table 5. The optimum solution for Example 2

\begin{tabular}{ccccccccccc}
\hline $\begin{array}{c}\text { Site / } \\
\text { supply }\end{array}$ & 1 & \multicolumn{2}{c}{2} & \multicolumn{2}{c}{3} & 4 & Supply \\
\hline 1 & 10 & 0 & 2 & 5 & 20 & 0 & 11 & 10 & 15 \\
2 & 12 & 0 & 7 & 10 & 9 & 15 & 20 & 0 & 25 \\
3 & 4 & 5 & 14 & 0 & 16 & 0 & 18 & 5 & 10 \\
Demand & 5 & \multicolumn{1}{c}{15} & \multicolumn{1}{c}{15} & 15 & Total 50 \\
\hline
\end{tabular}

The objective function value is: $F(x)=5 \cdot 4+5 \cdot 2+$ $+10 \cdot 7+15 \cdot 9+10 \cdot 11+5 \cdot 18=\$ 435$.

This is the optimum solution according to premium solver platform as shown in Table 6 as the same in objective function, but the computer solution is faster than the manual solution.

Also Lindo software is the same objective function but it is slower than premium solver platform. Figures 4, 5 illustrate how to solve transportation problem input objective function and constraints. After you press solve from the tool bar, you can see the final solution as shown in Figures 4, 5.
Table 6. The optimum solution according to premium solver platform software

\begin{tabular}{cccccc}
\hline $\begin{array}{c}\text { Site / Cost } \\
\text { to center }\end{array}$ & \multicolumn{4}{c}{$\begin{array}{c}\text { Transportation cost } \\
\text { to center }\left(c_{i j}\right)\end{array}$} & $\begin{array}{c}\text { Availa- } \\
\text { bilities } \\
\left(b_{i}\right)\end{array}$ \\
\hline Plant & 1 & 2 & 3 & 4 & \\
1 & 10 & 2 & 20 & 11 & 15 \\
2 & 12 & 7 & 9 & 20 & 25 \\
3 & 4 & 14 & 16 & 18 & 10 \\
$\begin{array}{c}\text { Requirements } \\
\left(d_{i}\right)\end{array}$ & 5 & 15 & 15 & 15 & \\
\hline
\end{tabular}

Decision

variables

\begin{tabular}{|c|c|c|c|}
\multicolumn{3}{c}{ Variables $\left(x_{i j}\right)$} & \\
\hline 0 & 5 & 0 & 10 \\
\hline 0 & 10 & 15 & 0 \\
\hline 5 & 0 & 0 & 5 \\
\hline
\end{tabular}

Constraints
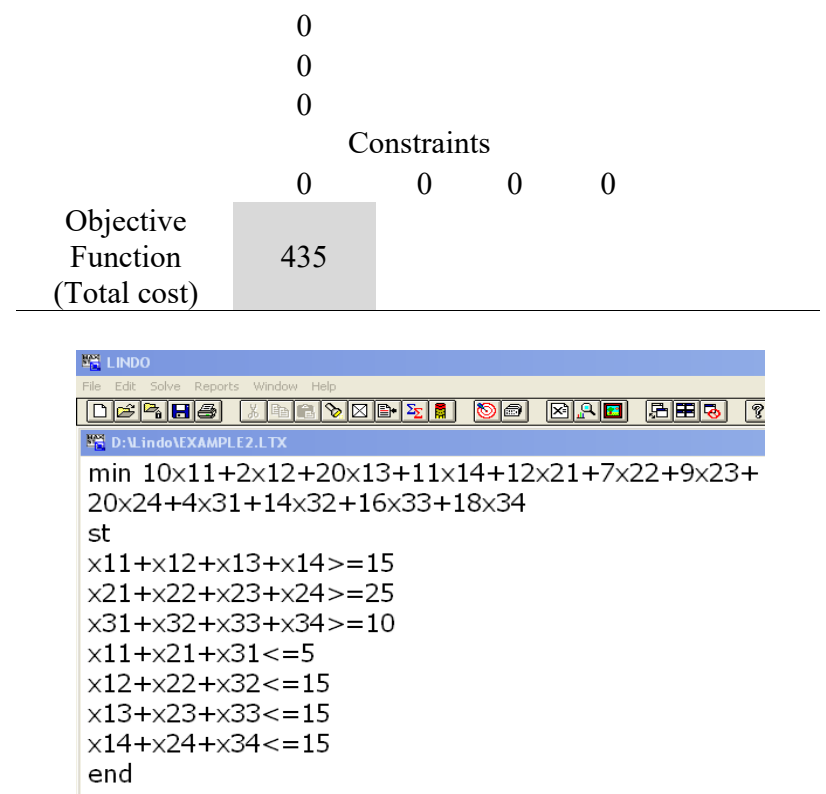

Figure 4. The objective function and constraints

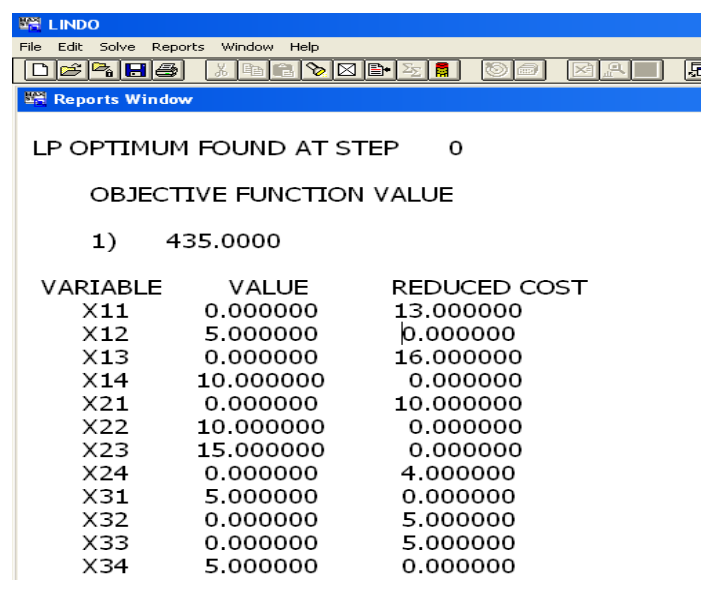

Figure 5. Final results after software run

\section{RESULTS}

Gomah \& Samy (2009) have given an optimum solution for the case study 2 and estimated the objective function at $\$ 475$. This is not the optimum solution because as we proved in this paper, there are two software 
methods which give the optimum solution and minimum for objective function at the amount of $\$ 435$. So the solution in this article is optimum and faster than others as mentioned in Ali, 2007; El-Beblawi, Mohamed, ElSageer, \& Mahrous, 2007; Ali \& Sik, 2012.

\section{CONCLUSIONS}

From the results obtained in this study, it is found that:

- the transportation problems can be solved by using the simplex methods, which is a time-consuming solution. Linear programming computer software is set up to solve both simplex and transportation problems. When the problem is introduced, the computer algorithm can solve it much faster and better;

- Lindo software is a tool which allows to use few manual methods, but much care should be taken in the input of the data and their constraints and solves linear programming problems for transportation with limited dimensions;

- Premium Solver Platform is used to solve (linear, non linear programming) large scale transportation problems as a special case. PSP is easier to use than Lindo software in terms of data input.

\section{ACKNOWLEDGEMENTS}

I would like to thank the Faculty of Engineering at Al-Azhar University Qena Branch for encouraging me to prepare and finish this paper.

\section{REFERENCES}

Abdelkhalik, A.S., \& Mostafa, M.M. (1977). Some TechnicoEconomical Factors Affecting the Cost and Evaluation of Some Phosphate Ores. In First Conference of Mining and Metallurgical Technology (pp. 107-109). Assiut, Egypt: Assiut University.

Ali, M.A.M. (2007). Design and Planning of Some Building Materials Quarries for Different Purposes in Sohag and Quena Governorates. PhD. Assiut, Egypt: Assiut University.

Ali, M.A.M., \& Sik, Y.H. (2012). Transportation Problem: A Special Case for Linear Programing Problems in Mining Engineering. International Journal of Mining Science and Technology, 22(3), 371-377.

https://doi.org/10.1016/j.ijmst.2012.04.015
Antipin, A.S., \& Khoroshilova, E.V. (2015). Linear Programming and Dynamics. Ural Mathematical Journal, (1), 3-19. https://doi.org/10.15826/umi.2015.1.001

Astola, H., \& Tabus, I. (2016). On the Linear Programming Bound for Linear Lee Codes. SpringerPlus, 5(1). https://doi.org/10.1186/s40064-016-1863-8

Da Gama, C.D. (2013). Easy Profit Maximization Method for Open-Pit Mining. Journal of Rock Mechanics and Geotechnical Engineering, 5(5), 350-353. https://doi.org/10.1016/j.jrmge.2013.07.001

David, G.L. (1984). Linear and Non Linear Programming. Stanford, California: Addison-Wesley Publishing Company.

El-Beblawi, M., Mohamed, A.Y., El-Sageer, H., \& Mahrous, A.M. (2007). Comparison Between Some Methods Used in Solving Transportation Problems. In The 10th International Mining, Petroleum and Metallurgical Engineering Conference March (pp. 290-300). Suez, Egypt: Suez University.

Gomah, T.I.G.E.M., \& Samy, I. (2009). Solving Transportation Problem Using Object-Oriented Model. International Journal of Computer Science and Network Security, (9), 355-361.

Ilich, N. (2008). Shortcomings of Linear Programming in Optimizing River Basin Allocation. Water Resources Research, 44(2), 1-14. https://doi.org/10.1029/2007wr006192

Loomba, N.P. (1964). Linear Programming: An Introductory Analysis. New York, United States: McGraw-Hill.

Peter, W. (2005). Linear Optimization with Microsoft Excels. Ontario, Canada: Faculty of Mathematics University of Waterloo.

Qi, Z., Tian, Y., \& Shi, Y. (2012). Regularized Multiple Criteria Linear Programming via Linear Programming. Procedia Computer Science, (9), 1234-1239. https://doi.org/10.1016/i.procs.2012.04.134

Rao, S.S. (1978). Optimization Theory and Application. New Delhi, India: Wiley Eastern Limited.

Reeb, J., \& Leavengood, S. (2001). Transportation Problem: A Special Case for Linear Programming Problems. Operation research Society of America, 1-35.

Saul, I.G. (1957). Linear Programming-Methods and Applications. New York, United States: McGraw-Hill.

Shalaby, Z. (2000). Solving Linear Programming Models by Spreadsheet Software Packages. Journal of King Abdulaziz University-Economics and Administration, 14(2), 3-9. https://doi.org/10.4197/eco.14-2.1

Waqar Ali Asad, M., \& Dimitrakopoulos, R. (2012). Optimum Production Scale of Open Pit Mining Operations with Uncertain Metal Supply and Long-Term Stockpiles. Resources Policy, 37(1), 81-89. https://doi.org/10.1016/i.resourpol.2011.12.002

\section{ЗАСТОСУВАННЯ ПРОГРАМНОГО ЗАБЕЗПЕЧЕННЯ У ВИРІШЕННІ ТРАНСПОРТНИХ ПРОБЛЕМ ГІРНИЧОВИДОБУВНОЇ ГАЛУЗІ}

\section{Магроус А.М. Алі}

Мета. Виявлення і вирішення транспортних проблем гірничих підприємств на основі моделей перевезень, побудованих методом лінійного програмування у комп'ютерних програмних продуктах LP Softwares.

Методика. Для вирішення транспортних і технологічних завдань у гірничодобувній галузі застосовані програмні продукти Lindo Software та Premium Solver Platform.

Результати. У статті розглянуті способи вирішення транспортних завдань “вручну” та за допомогою комп'ютерних програм. Отримано оптимальні рішення для проблем, які $\epsilon$ або можуть виникнути на гірничому підприємстві в майбутньому при різних умовах. Отримано аналогічні результати при вирішенні задач наступними п'ятьма способами: метод північно-західного кута, метод мінімальної вартості, мінімальний тариф за рядком, мінімальний тариф за стовпцем і метод апроксимації Фогеля.

Наукова новизна. Принципово новим $є$ застосування комп'ютерних програм LP Softwares у гірничодобувній галузі та отримання на їх підставі оптимального результату у вирішенні гірничотехнічних проблем з урахуванням обмежуючих умов. 
Практична значимість. Всі запропоновані підходи дозволяють оптимально вирішувати завдання не лише у гірничодобувній галузі, а й у інших галузях промисловості.

Ключові слова: транспортна задача, лінійне програмування, “пошук рімення” в Microsoft Excel, програма Lindo

\section{ПРИМЕНЕНИЕ ПРОГРАММНОГО ОБЕСПЕЧЕНИЯ В РЕШЕНИЯХ ТРАНСПОРТНЫХ ПРОБЛЕМ ГОРНОДОБЫВАЮЩЕЙ ОТРАСЛИ}

\section{Магроус А.М. Али}

Цель. Выявление и решение транспортных проблем горных предприятий на основе моделей перевозок, построенных методом линейного программирования в компьютерных программных продуктах LP Softwares.

Методика. Для решения транспортных и технологических задач в горнодобывающей отрасли применены программные продукты Lindo Software и Premium Solver Platform.

Результаты. В статье рассмотрены способы решения транспортных задач “вручную” и при помощи компьютерных программ. Получены оптимальные решения для проблем, которые имеются или могут возникнуть на горном предприятии в будущем при различных условиях. Получены аналогичные результаты при решении задач следующими пятью способами: метод северо-западного угла, метод минимальной стоимости, минимальный тариф по строке, минимальный тариф по столбцу и метод аппроксимации Фогеля.

Научная новизна. Принципиально новым является применение компьютерных приложений LP Softwares в горнодобывающей отрасли и получение на их основании оптимального результата в решении горнотехнических проблем с учетом ограничивающих условий.

Практическая значимость. Все предлагаемые подходы позволяют оптимально решать задачи не только в горнодобывающей отрасли, но и в других отраслях промышленности.

Ключевые слова: транспортная задача, линейное программирование, “поиск решения” в Microsoft Excel, программа Lindo

\section{ARTICLE INFO}

Received: 17 October 2017

Accepted: 12 January 2018

Available online: 17 January 2018

\section{ABOUT AUTHORS}

Mahrous A.M. Ali, Doctor of Philosophy, Assistant Professor of the Mining and Petroleum Engineering Department, Al-Azhar University, Maskan Osman, 83215, Qena, Egypt. E-mail: mahrous_mining@yahoo.co.uk 